\title{
The Long Shadow of Colonial Cartography: Britain and the Sino-Indian War of 1962
}

\author{
PAUL M. McGARR \\ Department of American and Canadian Studies, University of Nottingham, UK
}

\begin{abstract}
This article examines British responses to the Sino-Indian border war of 1962. It illustrates how, in the years leading up to the war, Britain's colonial legacy in the Indian subcontinent saw it drawn reluctantly into a territorial dispute between Asia's two largest and most powerful nations. It analyses disagreements in Whitehall between the Foreign Office and Commonwealth Relations Office over the relative strength of India and China's border claims, and assesses how these debates reshaped British regional policy. It argues that the border war was instrumental in transforming Britain's post-colonial relationship with South Asia. Continuing to filter relations with India through an imperial prism proved unsatisfactory; what followed was a more pragmatic Indo-British association.
\end{abstract}

KEY WORDS: India, China, Sino-Indian border, Foreign Office, Commonwealth Relations Office.

If two giant countries, the biggest countries of Asia, are involved in conflict, it will shake Asia and shake the world. It is not just a little border issue, of course. But the issues surrounding it are so huge, vague, deep-seated and far-reaching, inter-twined even, that one has to think about this with all the clarity and strength at one's command, and not be swept away by passion into action which may harm us instead of doing us good.

Jawaharlal Nehru, Indian prime minister, 27 November $1959 .^{1}$

On 20 October 1962, a border dispute between India and the People's Republic of China (PRC), that had blighted relations between the two nations from the late 1950s, erupted into open warfare. ${ }^{2}$ A rapid succession of Chinese thrusts into northern India

\footnotetext{
${ }^{1}$ Jawaharlal Nehru, India-China Relations', Speech delivered in Lok Sabha, 27 November 1959 (New Delhi: Publications Division, Ministry of Information and Broadcasting, Government of India, 1959).

${ }^{2}$ Aspects of the Sino-Indian border war have been addressed in work by Amit R. Das Gupta and Lorenz M. Luthi (eds.), The Sino-Indian War of 1962: New Perspectives (London: Routledge, 2017); Steven A. Hoffmann, India and the China Crisis (Berkley: University of California Press, 1990); Neville Maxwell, India's China War (London: Cape, 1970); Yaccov Vertzberger, Misperceptions in Foreign Policy Making: The Sino-Indian Conflict 1959-1962 (Boulder, CO: Westview Press, 1984); Liu Xuecheng, The Sino-Indian Border Dispute and Sino-Indian Relations (Lanham, MD: University Press of America, 1994); and Srinath Raghavan, War and Peace in Modern India: A Strategic History of the Nehru Years (Ranikhet: Permanent Black, 2010), amongst others.
} 
left the Indian Army reeling, and the country's political leadership in a state of panic. Speaking to a shell-shocked nation on All-India Radio on 22 October, the Indian prime minister, Jawaharlal Nehru, warned his fellow citizens to prepare themselves for a long and arduous struggle with China. The outbreak of Sino-Indian hostilities, a disconsolate Nehru cautioned, represented nothing less than the 'the greatest menace that has come to us [India] since independence. ${ }^{3}$ Echoing Nehru's injunction that India stood at a crossroads, Britain's high Commissioner in New Delhi, Sir Paul Gore-Booth, counselled London that, 'Countries as well as men have their moments of truth. It is no exaggeration to say that the Chinese invasion [has] brought India to such a moment; one has the impression that nothing here will ever be quite the same again.' 4 An atmosphere of jingoism gripped India. Rowdy anti-Chinese demonstrations occurred in major cities. Citizens committees sprung up to co-ordinate acts of patriotism and defiance that included donating blood and knitting for the jawans, or soldiers. A State of Emergency was declared, a National Defence Fund established, a programme of governmental austerity introduced, and recruiting stations for India's armed forces were flooded with eager volunteers. ${ }^{5}$

From the Indian government's perspective, an unwelcome imperial inheritance complicated the nation's cartographic conflict with China. During the period of British colonial governance in the subcontinent, London had favoured a policy of ambiguity with respect to India's Himalayan borders. One Whitehall official underlined that prior to Indian independence in August 1947, Britain's '...basic policy towards India's northern frontier was primarily one of convenience. It suited us best that the border should not be clearly defined: changed circumstances might make some adjustment desirable. This explains in large part the inconsistences of the maps of the time and the absence in many of them of any defined border. ${ }^{6}$ As a result, in the eastern Himalayas, India and China both claimed sovereignty over 90,000 square kilometres (35,000 square miles) of territory, roughly approximating to the present Indian state of Arunchal Pradesh. A second Sino-Indian territorial dispute centred on ownership of the Aksai Chin plateau, 38,000 square kilometres (14,700 square miles) of arid desert, wedged between the Indian region of Ladakh, Tibet, and the Chinese province of Xinjiang.

In the context of a weak China, a virtually autonomous Tibet, and an expansive Russia, capricious cartography served the British $R a j$ well. However, once the Union Jack had been lowered for the last time in South Asia, such opacity weakened the Indian government's claim that a 'customary and traditional' boundary delineated the nation's northern border with China. ${ }^{7}$ Moreover, the toxic legacy of contested national borders that Britain bequeathed independent India, rebounded to the formers disadvantage, complicating London's post-colonial relations with New Delhi and Beijing. In the 1950s, British governments sought to avoid becoming publicly enmeshed in the Sino-Indian border dispute. Yet, by February 1963, a senior Foreign Office (FO) official noted ruefully that events had made it, "hard to escape the

\footnotetext{
${ }^{3}$ The Times, 23 October 1962.

${ }^{4}$ Gore-Booth to CRO, 28 December 1962, FC 1061/20, FO 371/170669, The United Kingdom National Archives, Kew [henceforward TNA]

${ }^{5}$ Gore-Booth to Saville Garner, 26 October 1962, DO 196/75, TNA; Maxwell, India's China War, 414; The Times, 27 October 1962.

${ }^{6}$ Emery (CRO) to Flack (FO), 12 December 1963, FC 1061/141, FO 371/170675, TNA.

${ }^{7}$ Ibid.
} 
conclusion that we [Britain] share some historical responsibility for their [India's] present predicament." 8

The British government's reluctance to intervene in the border controversy was informed by concern that becoming entangled in a complex and emotive territorial dispute between India and China could damage the United Kingdom's relations with India, or China, and potentially both nations. General guidance issued by the Commonwealth Relations Office (CRO), the body responsible for relations with members of the Commonwealth of Nations, or Britain's former colonies, emphasised 'that this is primarily a dispute between India and China and it is not for the U.K. to interfere.' Quite aside from the risks that British engagement posed to the country's international interests, Whitehall considered that, given India's policy of nonalignment, New Delhi 'would be embarrassed by too public or obvious expression of our support.' Moreover, 'too explicit support for India from the West might only stimulate more explicit support for China from the Soviet Union', thus transforming a regional problem into a wider Cold War issue. ${ }^{9}$

Nevertheless, the CRO went to considerable lengths to assure Indian officials that Britain's silence on the border question did not imply a lack of support for a fellow Commonwealth nation. In October 1959, Sir Alexander Clutterbuck, permanent under-secretary at the CRO, underscored to Azim Husain, India's deputy high commissioner in London, that British 'restraint on the subject in public... was deliberate, but did not of course mean that we lacked sympathy or concern.' Although expressing understanding for Britain's position, Husain made it clear that escalating Sino-Indian tension had placed Jawaharlal Nehru in 'a most difficult situation.' Above all, Indians were clamouring for a robust response to China's renunciation of New Delhi's territorial claims. Faced with 'a growing public demand for firm action,' Husain indicated that China's 'intransigent' attitude might compel Nehru 'to do something to meet public opinion.' 10

Britain's response to the smouldering Sino-Indian border row was further complicated by disagreements between the CRO and Foreign Office over which party to the dispute was primarily to blame for the failure to reach a negotiated settlement. The CRO sympathised with the Indian government's contention that a combination of engrained cultural factors and mounting domestic pressures, had led China to adopt an aggressive and bellicose attitude towards its neighbours. 'We knew enough history to realise that a strong China is normally an expansionist China,' Nehru informed fellow Indians. 'That has been the case throughout history. And we saw, or we felt, that two factors, the great push towards industrialisation of that country, and the amazing pace of its population increase, taken together, would create a most dangerous situation. ${ }^{11}$ With the Indian premier's warning in mind, CRO officials complained bitterly to colleagues in the FO that guidance the latter had issued to British diplomatic posts abroad 'whitewashed' Chinese culpability for a series of border skirmishes. ${ }^{12}$

In August 1959, Chinese and Indian forces clashed near the village of Longju, astride the McMahon Line, a contested boundary dating from the British colonial period, at the eastern extremity of Himalayan range. Two months later, on 21 October, nine members of an Indian police patrol in Ladakh, at the opposite end of the two-thousand-mile long Sino-Indian border, were killed in a confrontation with

\footnotetext{
8 Norton minute, 8 February 1963, FC 1061/30, FO 371/170670, TNA.

9 'The Sino-Indian Border Dispute,' undated c. November 1959, DO 133/148, TNA.

${ }^{10}$ Clutterbuck minute, 30 October 1959, DO 133/148, TNA.

${ }^{11}$ Nehru, India-China Relations.

${ }^{12}$ Dalton (FO) to Twist (CRO), 3 December 1959, DO 133/148, TNA.
} 
Chinese troops. Neither of these events, the FO maintained, was evidence that Beijing had 'embarked on some deliberate policy of aggression against India.' The Foreign Office noted that no Chinese government had ever formally accepted the McMahon Line, or any specific demarcation of the western frontier in Ladakh. Rather than seeking to 'provoke an incident' with India on the border, as the CRO implied, the FO suggested that the spiral of armed clashes, 'had in a sense been forced on the Chinese and it seems to us that they would probably much rather have seen a continuation of the status quo in these areas. 13

Well into 1960, the Foreign Office continued to issue guidance to British embassies that cut-across the grain of the Commonwealth Relations Office's stance on the border dispute. The FO represented fresh Chinese military deployments on the border as a defensive response to a Tibetan uprising in 1959, the suppression of which had underscored Beijing's determination to uphold 'traditional' and long-established territorial claims. ${ }^{14}$ Earlier in the decade, Sino-Indian relations had blossomed following the signing in 1954 of the Panch Sheel accord, or 'Five Principles of Peace Co-existence', which encompassed commitments to non-aggression and respect for national sovereignty. ${ }^{15}$ Three years later, New Delhi and Beijing clashed after China constructed a highway between Xinjiang and the rebellious region of Western Tibet, part of which bisected the Aksai Chin plateau. In turn, Nehru's government infuriated China by granting political asylum to Tibet's spiritual leader, the Dalai Lama, and thousands of his followers, in the wake of the abortive Tibetan revolt. ${ }^{16}$ Moreover, in November 1959, as the head of India's intelligence bureau conceded to British diplomats, New Delhi had embarked on a controversial strategy that would become known as the 'Forward Policy'. Under this initiative, Indian outposts had been established, ' 20 miles or so in advance of the true [Sino-Indian] frontier.' 17

As friction between the Indian and Chinese governments mounted, New Delhi looked to British archives to bolster the legal basis of its territorial claims. In this sense, Britain's colonial legacy in South Asia acted as magnet, drawing a reluctant Whitehall into a cartographic conflict between Asia's two largest and most powerful states. Addressing India's parliament toward the end of 1959, Nehru noted that China had gone on to the offensive in a battle of maps:

\footnotetext{
${ }^{13}$ Dalton to Twist, 3 December 1959, DO 133/148, TNA.

${ }^{14}$ Recent scholarship examining China's approach to border disputes has largely endorsed the FO's judgment that Beijing was willing to make pragmatic territorial concessions to secure negotiated settlements. See, M. Taylor Fravel, Strong Borders, Secure Nation: Cooperation and Conflict in China's Territorial Disputes (Princeton: Princeton University Press, 2008). Similar arguments surrounding China's approach to territorial disputes are repeated in, Eric Hyer, The Pragmatic Dragon: China's Grand Strategy and Boundary Settlement (Vancouver: University of British Columbia Press, 2015). For a different perspective, but one that also underlines China's pragmatic approach to border issues, see, Zhihua Shen and Julia Lovell, 'Undesired Outcome: China's Approach to Border Disputes during the Early Cold War,' Cold War History 15:1 (2015): 106-107.

${ }^{15}$ A. Appadorai (ed.), Select Documents on India's Foreign Policy and Relations, 1947-1972, vol. 1 (New Delhi: Oxford University Press, 1982), 459-66. [ičpi]

16 'Chinese Intentions against India,' Joint Intelligence Committee (JIC) report, 22 iscepi] November 1962, CAB 158/47, TNA; See also Sarvepalli Gopal, Jawaharlal Nehru: A Biography, vol. 3: 1956-1964 (London: Jonathan Cape, 1984), 81 and 89, and Robert J. McMahon, 'U.S. Policy toward South Asia and Tibet during the Early Cold War', Journal of Cold War Studies, 8,3 (2006), 141. For a Chinese perspective on Sino-Indian relations see Chen Jian, Mao's China and the Cold War (Chapel Hill: University of North Carolina Press, 2001), 78-9.

${ }^{17}$ White to Dobbs and Anderson, 19 November 1959, DO 133/148, TNA.
} 
The Chinese Government has recently published a kind of atlas, - atlas is not perhaps the right word -a collection of maps. I think two or three are their own maps. The others are maps taken from other countries, which they thought to some extent helped their case. Among them are some travellers' maps and maps from the Encyclopaedia Britannica. Some of these help them a little, some of them more. We have plenty of maps, too, and very good maps. I have no doubt that our case is a strong one. ${ }^{18}$

The Nehru government's interest in obtaining British maps and documents that supported its position on the border demarcation dispute, saw Indian officials dispatched to London on a hunt for evidence. Under the direction of Sarvepalli Gopal, the director of the historical division of India's Ministry of External Affairs (MEA), New Delhi's emissaries combed through dusty files in the India Office records at the CRO. ${ }^{19}$ In September 1959, India's bid to procure a facsimile of a British map of Ladakh, which had been drawn up in 1851, developed into a saga worthy of a John le Carré espionage novel. On instruction from Gopal, the Indian high commission in London arranged with the CRO and the Indian Office Library (IOL) to loan the map for the purposes of making a photostat copy. Having collected the map from the IOL, an Indian clerk at the high commission, K. L. Madan, boarded a bus to return to India House. During his journey Madan was approached by a fellow passenger, who he believed to be Chinese, and offered $£ 100$ in cash for the map, along with the promise that a further $£ 100$ would be made available to two of his colleagues at the high commission. Having rebuffed the offer, a flustered Madan hastened back to India House.

Alarmed by what appeared to have been a crude operation mounted by Chinese intelligence agents to obtain the sole copy of a map that strengthened New Delhi's border claims, the Indian high commission alerted the CRO. On 28 September, during an interview with Alexander Clutterbuck, Azim Husain suggested that the IOL place additional restrictions on public access to maps and documents relevant to the border dispute. Clutterbuck agreed to implement tougher access standards, the effect of which was to ensure that only British and Indian officials were able to consult politically sensitive material held by the IOL. The Indian high commission also tightened its own security procedures. Reasoning that Chinese intelligence operatives had learned of Indian plans to acquire the Ladakh map by tapping into India House's telephone lines, staff working for the high commission were instructed not to discuss any important matters over the telephone. ${ }^{20}$ In October, when Gopal returned to Britain to undertake further research on the border question, he received police protection to forestall 'dirty tricks' on the part of the Chinese. ${ }^{21}$

Discreet assistance extended to India by Whitehall was complicated by a growing conviction inside Nehru's administration that, on the border issue, at least, the British establishment and press sympathized with China. In January 1960, Nehru's sister, and India's high commissioner in London, Vijayalakshmi Pandit, informed William Haley, the editor of the London Times, that her brother, had become 'very worried' that the Chinese government had taken to quoting extracts from the Times in support of their position on the border. Implying that the Times had been less than impartial in its coverage of the Sino-Indian territorial dispute, Pandit revealed the Indian government's fear 'that [Chinese premier] Chou-en-Lai would make great play with

\footnotetext{
${ }^{18}$ Nehru, India-China Relations.

${ }^{19}$ Delhi to CRO, No. 39, 9 January 1960, DO 133/148, TNA.

${ }^{20}$ Vijaya Lakshmi Pandit to Jawaharlal Nehru, Prime Minister's House, New Delhi, TOP SECRET, No. 45-HC/59, 1 October 1959, Subject File 62, $1^{\text {st }}$ Instalment, Vijaya Lakshmi Pandit Papers, NMML. ${ }^{21}$ Dobbs to Anderson, 26 February 1960, DO 133/148, TNA.
} 
this [the Times' reporting] in some subsequent note [to New Delhi]. ${ }^{22}$ Later that month, Azim Husain complained to Lord Home, secretary of state for commonwealth relations, that Chinese officials were referencing a map printed by the Times in 1959, which described territory south of the McMahon Line as disputed. 'The Chinese had claimed that The Queen's cartographer had drawn the map in this way,' Husain fulminated, 'so that clearly India was in the wrong in saying that it was Indian territory. ${ }^{23}$

In a bid to correct what the Indian high commission perceived to be excessive proChinese coverage in the newspapers letters page, Husain despatched two long letters to Haley. The first of these had been published by the Times in full. The second, which Husain regarded as 'much more important,' was printed only in a much truncated form. Dissatisfied with the treatment he received from Haley, Husain changed tack, and sought help from Sir Olaf Caroe, who agreed to submit 'an authoritative article' to the Times in support of India's stance on the territorial dispute. As a former provincial governor in British India, and latterly a prominent commentator on Asian geo-politics, Husain was optimistic that Caroe's intervention would encourage the British press to take India's side in Sino-Indian quarrel. By way of added insurance, Husain extracted a commitment from Lord Home that, should the Times decline to carry Caroe's essay, the CRO would approach Haley directly in an effort to have the decision overturned. ${ }^{24}$

The Times duly rejected Caroe's article, causing Home to wade into the issue of 'the Indian Government's dissatisfaction with The Times over frontier territories.' Calling on Haley, Home voiced concern that Nehru's administration had come to view the Times, a newspaper lauded as the voice of Britain's establishment, as 'hostile to India.' Printing Caroe's paper, Haley was counselled, would serve as a palliative in New Delhi, and help to dispel misconceptions in India that Britain was a fairweather friend. Haley was unmoved by Home's intervention, angrily dismissing Indian complaints against his newspaper as baseless and misguided. Recording the encounter with the secretary of state in his diary, the Times' editor seethed:

I told Hume [sic] that I had been through all this before with Mrs. Pandit. Far from being one sided against India, The Times had published a number a number of letters giving the Indian case each time the matter had been raised. The balance of publication had certainly been on India's side because, in fact, we had received more letters that way than the other. But, of course, the Chinese would not quote these. ... Now they [the Indian government] were trying to apply another turn of the screw. They should be told it was quite useless. In our judgment the matter had been dealt with more than fairly. ${ }^{25}$

Having been rebuffed by the Times, the Indian high commission turned to another national newspaper, the left-of-centre Manchester Guardian, which did agree to publish Caroe's treatise on the border. Just as Home had feared, however, the Times' intransigence was resented in New Delhi, and strengthened the impression held by a growing number of Indian government officials that Britain was reluctant to support a fellow commonwealth member subject to Chinese aggression. In conversation with

\footnotetext{
${ }^{22}$ Diary entry 15 January 1960, GBR/0014/HALY/15/2, 'Times' Diaries, Churchill Archives Centre, Churchill College Cambridge (hereafter HCAC).

${ }^{23}$ Record of Conversation between Home and Husain, 2 February 1960, DO 133/148, TNA.

24 'Ibid.

${ }^{25}$ Diary entry 10 February 1960, GBR/0014/HALY/15/2, HCAC.
} 
British diplomats in India, Gopal complained that by adopting what he characterised as a notably pro-Chinese editorial line on an issue of such crucial importance to India, the Times' risked undermining British interests in the subcontinent. In the space of a few weeks, Gopal observed pointedly, Haley's newspaper had refused to print articles affirming India's arguments on the border dispute that had been submitted not only by Caroe, but also by Hugh Richardson, a former Indian Civil Service officer and authority on Tibet. In contrast, over the same period, the Times had published letters endorsing the Chinese viewpoint that had been written by Han Suyin, otherwise known as Elizabeth Comber, the notable Eurasian author and Sinophile, and Sir Henry Twynam, a former governor of British India's Central Provinces. Influential members of the British press, Gopal carped, including Richard Harris, the Far Eastern editor of the Times, who had lived in China for a number of years, were pursuing a pro-Chinese and anti-Indian agenda. In a lecture Harris had delivered at Chatham House, Gopal claimed, the journalist had implied that the, 'Chinese had a much superior civilization to India, deserved to become the dominating power in the area, and the sooner the Indians realised this the better. ${ }^{26}$ As Indian sentiment on the border issue turned increasingly febrile, the London correspondent of the Hindustan Times, took to admonishing the Britain for 'sitting on the fence over the border dispute. $^{27}$

Whitehall's disquiet at Indian charges of British partisanship in relation to the border dispute was tempered by a suspicion that New Delhi's sensitivity on the issue was driven more by political pressures inside the subcontinent, than any genuine conviction that the British establishment had failed to come to terms with the end of the Raj, and was inherently anti-Indian. The CRO suspected that Nehru was willing to cede territory to China to secure a border accord, but had ruled this out on the grounds that the Indian electorate would interpret any concessions as intolerable and akin to appeasement. Notably, in March 1962, a general election in India witnessed a significant upsurge in support for the Right-wing Jan Sang party, especially in the Hindi-speaking heartland of northern India. This development effectively killed off any realistic prospect of a Sino-Indian accommodation. ${ }^{28}$

London took additional solace in a misconception that Chinese hostility toward India was likely to remain rhetorical and, even were this proved not to be the case, plans for military action could be exposed and neutralized before things got out of hand. The UK high commission in Calcutta brushed off security concerns raised by British residents in Darjeeling, in eastern India, close to the disputed McMahon line. Seeking to reassure their nervous compatriots, British officials insisted that, 'Indian intelligence sources were sufficiently good to rule out the possibility of China launching a surprise large-scale attack on India (even if, which was not the case, we thought that she intended to do so). The build-up on the Chinese side of the frontier which would be needed could not possibly be concealed.' ${ }^{29}$

The events of October 1962 made a mockery of British calculations that the border conflict would remain an on-going diplomatic irritant in the wider context of Sino-

\footnotetext{
${ }^{26}$ Dobbs to Anderson, 18 February 1960, DO 133/148, TNA. Richard Harris delivered a lecture entitled, 'China and the World', at Chatham House on 11 November 1958. The address was reprinted in International Affairs, Vol. 35, No. 2 (April 1959), pp. 161-169. There is nothing in the text of Harris' speech to substantiate Gopal's charge of anti-Indian bias. India is hardly mentioned by Harris, who does not, either explicitly or implicitly, claim superiority on the part of Chinese civilisation that India should accommodate.

${ }^{27}$ Belcher minute, 28 July 1962, FC 1061/53, FO 371/164912, TNA.

${ }^{28}$ Gore-Booth to CRO, 28 December 1962, FC 1061/20, FO 371/170669, TNA.

${ }^{29}$ Whitehead (Calcutta) to Smedly, undated, c. February 1960, DO 133/148, TNA.
} 
Indian relations. By the middle of the month, with Chinese and Indian forces heavily engaged, Whitehall dithered over whether to extend an unqualified expression of British support to India. The Foreign Office fretted that Nehru's government might consider the unsolicited intervention of an 'imperialist power' in the border war as an affront to Indian non-alignment, while China might react to British sabre rattling by escalating hostilities. ${ }^{30}$ Equally, London's relationship with New Delhi had experienced periods of considerable strain over the previous decade, most notably at the time of the Suez and Hungarian crises in 1956. Bilateral relations had bounced back from the nadir of Suez, but Britain's prime minister, Harold Macmillan, had little personal affection for Nehru, whom he considered smug and prone to acts of political hypocrisy. Nehru's rhetoric on non-violence, refusal to take sides in the Cold War, and sermons in support of African nationalism, all grated on Macmillan. ${ }^{31}$

It was only when India's embattled army faced, in Macmillan words, 'a bit of a Dunkirk' at the hands of the Chinese, and once the Kennedy administration in the United States had forcefully condemned Beijing's aggression, that the British government offered India its support. ${ }^{32}$ Prodded by the CRO, on 23 October, Macmillan sent Nehru a letter expressing Britain's sympathy for India's plight, and confirming his government's endorsement of the McMahon Line. ${ }^{33}$ Over the following twelve months, the Macmillan and Kennedy governments worked to leverage military, economic, and political assistance provided to Nehru's embattled government in an attempt to forge a, 'closer understanding, within their general policy of non-alignment, between India and the West.' This, in turn, it was envisaged, would establish the basis for a new collaborative relationship and see India adopt a less benign view of Soviet, as well as Chinese, communism. ${ }^{34}$ Moreover, in early November, during meetings held in London between British and American officials to coordinate the Western response to the border war, it was agreed by the Kennedy and Macmillan governments that, 'Whatever other action we may take to try and bring the fighting to a halt, we must do everything we can to prevent the Indian case being weakened.' In this regard, the Kennedy administration considered that Britain's Commonwealth connection to India afforded the UK greater latitude than the United States to assist New Delhi without compromising the appearance of Indian nonalignment. ${ }^{35}$

At the same time, another struggle ensued, in this instance at the very the heart of Britain's government, between the Foreign Office and colleagues within the CRO. Rooted in Whitehall's desire to make sense of the confused and contested historical context of the Sino-Indian border war, tensions between the FO and CRO developed into a broader debate over whether India or China was primarily to blame for the descent into conflict. By extension, rival bureaucratic camps led by the South Asia

\footnotetext{
30 'Expression of sympathy for India', 21 October 1962, FC 1061/86, FO 371/164914, TNA; Peck memorandum, 22 October 1962, FC 1061/92, FO 371/164914, TNA. Sičpi

${ }^{31}$ Alistair Horne, Macmillan, 1957-1986 (London: Macmillan, 1989), 415-16. SLẸ:

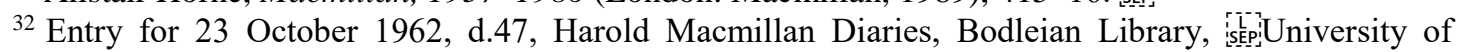
Oxford; Brubeck to Bundy, 15 October 1962, Foreign Relations of the United States (hereafter FRUS), 1961-1963, vol. XIX (Washington, DC: Government Printing Office, 1996), 341-2. [is.pi?

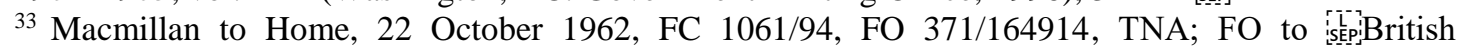
Embassies, No. 416 Guidance, 23 October 1962, DO 196/165, TNA. [S-

${ }^{34}$ CRO to Delhi and Karachi, 15 November 1962, FC1063/13 (B), FO 371/164929, TNA; Roger Hilsman, To Move a Nation: The Politics of Foreign Policy in the Administration of John F. Kennedy (New York: Delta, 1967), 331-2; Chester Bowles, Promises to Keep: My Years in Public Life, 1941-

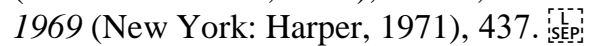

${ }^{35}$ Foreign Office Note, 23 November 1962, DO 191/99, TNA.
} 
Department of the CRO, and the Foreign Office's Far Eastern Department, clashed over the extent to which China should be considered as a perfidious and aggressive power best kept at arms-length, or, alternatively, a largely pragmatic state, with whom Britain could continue to cultivate beneficial relations. Spilling over into the public domain, such divisions fostered an impression of confused and schizophrenic British foreign policymaking, and injected familiar and unwelcome friction into London's relations with New Delhi.

Toward the end of 1962, once Indian and Chinese military forces had disengaged, and an uneasy ceasefire was in place at both ends of the Sino-Indian border, the Foreign Office approached Alistair Lamb in a bid to clarify the circumstances that had led Asia's two preeminent powers to come to blows. An historian, and author of Britain and Chinese Central Asia: The Road to Lhasa 1767-1905, Lamb had strong connections with Whitehall. ${ }^{36}$ His father, Lionel, or Leo as he was widely known, was a renowned Sinophile, who had served in a variety of British diplomatic posts in China between the wars. In the early 1950s, Leo Lamb ran the United Kingdom's Embassy in Beijing during a tumultuous period in Sino-British relations, dominated by the Korean War. From the Foreign Office's perspective, the younger Lamb's familiarity Asia and solid academic credentials, made him eminently qualified to assess the strength of Indian and Chinese territorial claims. Lamb's view, the FO contended, could be regarded 'as authoritative on this subject.' 37

Before the year was out, Lamb passed some rough notes to the Foreign Office 'in the hope that they may be of use.' In these, he drew upon the history of previous Chinese incursions into South Asia that had taken place in 1791 and 1842. Referencing Beijing's unexpected decision to end Sino-Indian hostilities on 20 November by declaring a unilateral ceasefire, Lamb argued that such behavior was, in fact, unsurprising. In the past, the FO was informed, China's forays across the Himalayas had followed a familiar pattern. Intractable territorial conflicts had been resolved through an initial show of overwhelming Chinese force, followed by a retreat that avoided the annexation of swathes of contested territory, and ultimately pursuit of a negotiated peace. In contrast, Lamb indicated that the Indian government had been less than consistent in its approach to the border dispute, and 'rather naughty' in misrepresenting evidence contained in British documents that attested to the strength of China's claims in both the eastern and western border sectors. ${ }^{38}$

In early 1963, Lamb produced a second, much longer, and more comprehensive report for the Foreign Office. This reinforced his earlier work, and cited detailed evidence that suggested China held a 'very strong' claim on the Aksai Chin plateau in Ladakh, and 'a good claim' on territory occupied by India at the opposite end of the Himalayas. The Foreign Office welcomed Lamb's conclusions, noting that they had 'more or less confirmed what we had always supposed.' Had Nehru displayed greater vision, FO officials reasoned, and acted before Indian public opinion turned decisively against a compromise settlement with China, the Indian government could have struck 'a fair bargain' by accepting Beijing's offer to trade recognition of the McMahon Line for Indian concessions in Ladakh. The Foreign Office was disconcerted, however, that Lamb's report not only listed 'several examples of Indian disingenuousness,' but went as far as to charge Indian officials with 'deliberately misquoting key documents' in a bid to strengthen New Delhi's case on the border

\footnotetext{
${ }^{36}$ Alistair Lamb, Britain and Chinese Central Asia: the Road to Lhasa 1767-1905 (London: Routledge \& K.Paul, 1960).

${ }^{37}$ McKenzie Johnston to Ledward (Washington), 4 March 1963, FC 1061/30, FO 371/170670, TNA.

38 Ibid.
} 
question. ${ }^{39}$ Stanley Sutton, of the India Office Library, corroborated Lamb's claim that Nehru's government had distorted evidence contained in British records that backed China's claim on Aksai Chin. Absolving such a 'competent' and 'honest' historian as Gopal from such sharp practice, instead Sutton speculated that it was more likely:

... some other Indian official... will have chosen to disregard Dr. Gopal's findings on this topic. One can see that this might have been done to make India's case more superficially impressive; or perhaps because Mr. Nehru was already committed to the distortion in correspondence with Chou En-lai by the time Dr. Gopal ascertained the true facts... ${ }^{40}$

Whatever the genesis of purported Indian mendacity, the Foreign Office took the counsel offered by Lamb and Sutton as confirmation that New Delhi's presentation of its territorial demands was, 'in places dishonest, and dangerously so, since....anyone who takes the trouble to consult the public record can show their [India's] dishonesty.' The risk that India's cartographic claims could be exposed as flawed, or worse still, duplicitous, led FO officials to question whether British ministers ought to begin hedging the 'unqualified' endorsement that had been extended in respect of the Nehru government's frontier demands following the outbreak of the border war. ${ }^{41}$ The likelihood that Chinese archival records would have alerted Beijing to weaknesses and inaccuracies in India's case, offered further reason to avoid becoming caught up in legal wrangles over the strength or otherwise of India's border claims. 'For our own purpose,' one FO official recorded, 'I think that Mr. Lamb's notes merely reinforce... that the less said by us the better.' 42

In Washington, the British embassy reacted equally warily to Lamb's report. In a message sent back to Whitehall, the embassy stated that it had decided against sharing Lamb's evaluation with the State Department, 'even informally.' British diplomats in the United States were concerned that their Americans colleagues would 'misunderstand' Britain's position, as outlined in the Lamb paper, as overly critical of India and unduly soft on China. 'It [Lamb's report] might in fact,' the British embassy worried, 'lead them [the Americans] to doubt the strength of our resolve to carry through the objectives of Anglo-American policy towards the border dispute agreed last November and possibly to pave the way for some joint peace-making endeavor.' Furthermore, the embassy in Washington concluded that it would be hard pressed selling Lamb's politically inconvenient conclusions to American counterparts, 'long trained in the principle that research done under government auspices should be "politically oriented.",43

British diplomats took comfort in the fact that one of their colleagues, John Addis, was then in the process of writing another analysis of the border dispute, which, it was hoped, would prove more politically palatable. Addis was in the United States enjoying an academic furlough at Harvard University's Center for International Affairs. A counselor in the British legation in China in the mid-1950s, Addis had returned to London to run the FO's Southern Department. Immediately prior to his arrival at Harvard, he had completed a two-year posting as Britain's ambassador to

\footnotetext{
${ }^{39}$ Ibid.

${ }^{40}$ Oliver minute, 18 June 1963, FC 1061/95, FO 371/170673, TNA.

${ }^{41}$ Buxton minute, 28 February 1963, FO 371/170670, FC 1061/30, TNA.

${ }^{42}$ McKenzie Johnston to Ledward (Washington), 4 March 1963, FO 371/170670, FC 1061/30, TNA.

${ }^{43}$ Ledward (Washington) to McKenzie Johnston, 21 March 1963, FC 1061/30, FO 371/170670, TNA.
} 
Laos. Whilst at Harvard, Addis elected to study the border dispute for two reasons. His experience in China had stirred an interest in Sino-Indian relations. Addis confessed to colleagues in the FO that the border issue had 'perplexed me since 1956.' More practically, Addis had access to a voluminous series of papers on the territorial question published by the Indian and Chinese governments. Aiming to sweep aside the emotive and politically charged exchanges that had come to characterize Indian and Chinese discourse on their common border, Addis envisaged that his study would, 'get the facts straight and stop short of conclusions and speculations. ${ }^{44}$ Within the Foreign Office, it was anticipated that an experienced diplomat, such as Addis, would produce a 'balanced basic document' that would include strong criticism of China and, in consequence, prove more acceptable to the Sinophobic Kennedy administration. ${ }^{45}$ In an effort to influence the tone and content of Addis' work, the assistant under-secretary of the FO's Far East Department, Ted Peck, who had served as a junior British official in Delhi in the early 1950s, kept a close eye on its progress.

Addis quickly concluded that the border dispute represented an unwelcome diversion from Beijing's perspective. Writing to Peck on 14 March, he suggested that the 'border question was not to their [China's] seeking, a tiresome distraction from more important issues elsewhere, an unwanted encumbrance which they consistently sought to eliminate.' It had been the Chinese, Addis contended, who from 1959 onwards had exhibited a willingness to reach a territorial settlement with India. Whereas the Indian government had refused 'to have useful talks' on the border problem, the Chinese had 'acted with restraint and forbearance in staying still on the border while the Indians advanced.' According to Addis' interpretation of events, the Chinese decision to initiate limited military action along the border in 1962 had been driven by a combination of political and strategic pragmatism. By restricting their military activity to the elimination of frontier posts that India had established on contested territory, and declaring a unilateral ceasefire with the offer of accompanying talks, Beijing had, Addis argued, inflicted a humiliating defeat on Nehru's government. Moreover, against the wider backdrop of Sino-Soviet tension, and the standoff between Washington and Moscow precipitated by the Cuban Missile Crisis in October, the Chinese government had provided a 'practical demonstration, after Khruschev's [sic] capitulation on $\mathrm{Cuba}$, on how to deal with problems of coexistence. $^{46}$

Peck read Addis' take on the border question with great interest, noting that 'there is little in them with which we [Foreign Office] should wish to quarrel.' In fact, Peck's only criticism of Addis was that he had underplayed the degree to which India's actions had served as the catalyst for Sino-Indian hostilities. 'We wonder,' Peck replied to Addis on 22 March, 'if the genesis of the Chinese campaign...could not be more precisely pinned down to Nehru's policy decision taken in 1961 against military advice, to infiltrate the Chinese lines in Ladakh. ${ }^{47}$ In turn, Addis conceded that he been disturbed by the 'sort of death-wish' that had characterized Indian actions in the lead up to hostilities. 'Mr. Nehru evidently saw clearly from the start that the course on which he was set led to war,' the British diplomat reasoned, 'and like the

\footnotetext{
44 Addis to Peck, 5 March 1963, FC1061/55, FO 371/170671, TNA.

${ }^{45}$ Ledward (Washington) to McKenzie Johnston, 21 March 1963, FC 1061/30, FO 371/170670, TNA.

${ }^{46}$ Addis to Peck, 14 March 1963, FC1061/55(A), FO 371/170671, TNA.

${ }^{47}$ Peck to Addis, 22 March 1963, FC1061/55, FO 371/170671, TNA.
} 
learner-driver of a motor-car warned to avoid the lamp-post in the middle of the road, he drove slap into it. ${ }^{48}$

Legal and strategic considerations aside, senior officials in the British government shared Addis' surprise at the ease with which the Chinese had managed to out maneuver the Indian government in communicating the veracity of their border claims to a wider international audience. In December 1962, Malcolm MacDonald, who had served as Britain's high commissioner in New Delhi in the 1950s, lamented that 'the Indians had handled their case very ineptly. ${ }^{49}$ The CRO grumbled that, 'The Chinese succeeded in making a poor case appear contestable; the Indians frittered away all their most telling arguments... Chinese experts must have had great delight in tearing the amateurish Indian arguments into shreds. ${ }^{, 50}$ On this point, for once, the Foreign Office was in total agreement with its colleagues at the CRO. Impressed by the "the absolute consistency with which the Chinese have presented their very presentable case', FO desk officers disparaged 'the wavering and often self-contradictory line taken by the Indians. ${ }^{51}$ In particular, the British considered that Radio Peking had shown itself 'highly skilled' in selectively quoting from Indian newspapers and the public statements of Indian leaders to present New Delhi as the aggressive party in the border quarrel. In an operation that the British Information Service in New Delhi considered to have "“out-Goebbels Goebbels", Chinese radio employed the services of an Irishman 'slightly reminiscent of Lord Haw Haw', who ensured that the theme of Indian belligerency was 'plugged so repetitively that something must certainly stick in the minds of Asian/African listeners, if not of other peoples also. ${ }^{52}$

Whitehall rued a dearth of sympathy and understanding for India inside the developing world in the wake of China's military offensive. British officials attributed a marked ambivalence to India's plight evident in Africa and Asia to the high-handed manner in which New Delhi conducted much of its international diplomacy. Paul Gore-Booth ruminated that the border conflict had taught India that, 'if you want goodwill from people in critical moments, you must not spend the rest of your time either ignoring them or loftily criticising their management of their affairs. ${ }^{53}$ In subtropical Africa, British diplomats deplored 'the inadequate public presentation... of the Indian case in regard to the frontier dispute with China.' Following one encounter with the Indian high commissioner to Ghana, J. C. Kakar, the British ambassador to Mali, Martin Le Quesne, marvelled at the extent to which his Indian colleagues had meekly surrendered to China in the propaganda sphere. Characterising Kakar's response to China's publicity work as 'wet', Le Quesne was taken aback by Indian defeatism. Kakar, Le Quesne reported despondently, 'agree[d] wholeheartedly that the Indians had failed to play the good cards in their hand and had let the Chinese take all the tricks, but seemed to regard this as being the natural order of things. One of those unfortunate facts of life about which nothing could be done. ${ }^{54}$

Things were little better in Asia. In Indonesia, in late November 1962, the British embassy in Djakarta reported that India's ambassador, Apa Pant, was 'almost at his wits' end' attempting to counter Indonesians' willingness to accept China's version of the border dispute. 'Seen from here,' Whitehall was advised by its embassy in

\footnotetext{
${ }^{48}$ Addis to MacLehose, 23 May 1963, FC1061/83, FO 371/170671, TNA.

${ }^{49}$ Conversation between Macdonald and Peck, 20 December 1962, FC 1061/8, FO 371/170669, TNA.

${ }^{50}$ Emery to Flack, 12 December 1963, FC 1061/141, FO 371/170675, TNA.

${ }^{51}$ Norton minute, 23 April 1963, FC1061/55, FO 371/170671, TNA.

${ }^{52}$ Kerr (New Delhi) to Bishop (CRO), 30 October 1962, DO 191/99, TNA.

${ }^{53}$ Gore-Booth to CRO, 28 December 1962, FC 1061/20, FO 371/170669, TNA.

${ }^{54}$ Le Quesne (Bamako) to Peck (FO), 26 January 1963, FC1061/36, FO 371/170670, TNA.
} 
Djakarta, 'the Chinese have carried out an entirely successful propaganda exercise designed to fog and bemuse uninformed and semi-informed opinion. Their official statement at the outset of the fighting were almost automatically taken at face value here and the first impression thus created has not been weakened seriously by anything said or done by the Indians since. ${ }^{55}$ In London, FO officials came to the stark conclusion that 'the Chinese are much better at propaganda than the Indian...' When it came to the border question, in particular, the Indian government appeared to be out of its depth in publicity terms. Put simply, the British judged that Nehru's government did, 'not know how to put their case across ... and it looks as if it is going to take them a long time to learn how to do it. ${ }^{56}$

Accounts of India's deficiencies in its propaganda war with China that filtered back to London from Africa and Asia were reinforced by British soundings taken in New Delhi. Following discussions with Indian officials, Gore-Booth was aghast to discover that although the border dispute had been rumbling on for a number of years, 'no proper briefing on the dispute had...ever been sent to Indian missions abroad [and] No guidance was available to such Indian Government organs of publicity as existed at the moment when the crisis broke.' In contrast, the High Commissioner noted, 'the Chinese propaganda machine was working flat out on carefully prepared material and argument. ${ }^{, 57}$

In part, the derision heaped on India's publicity effort by the British, and the patronising and paternalistic tone in which such criticism was couched, betrayed a lingering colonial mentality. The Foreign Office had long perceived Mao Zedong's China to be a more dynamic and vibrant nation than London's former Indian colony. Notably, the FO had reacted dismissively to the Kennedy administration's enthusiasm for utilising Western economic aid to transform India into an Asian bulwark against Chinese-inspired communist expansionism. In March 1962, Foreign Office officials reflected sardonically that, having absorbed 'incomparably more external aid' than the PRC, India had demonstrated that external assistance alone failed to provide a panacea for redressing 'backwardness'. The path to modernity was determined by the will and energy of the general populace, the FO contended, and although 'that upsurge of will and energy is certainly manifest in China: it does not yet seem to be very evident in India. ${ }^{58}$

Aside from concern that Britain risked hitching its wagon to a faltering Indian star, the Foreign Office saw strong pragmatic reasons for ensuring that support extended to New Delhi did not go so far as to provoke a schism in relations with the PRC. Not least, Britain retained a valuable trading stake in China, and had the security of Hong Kong to consider. To India's fury, just weeks after the cessation of the border fighting Macmillan's government welcomed Lu Hsu-Chang, China's vice-minister for foreign trade, to London. 'It is important for our trade with China that we do this', Lord Home informed Duncan Sandys, Secretary of State for Commonwealth Relations, '... we are so badly in need of export outlets it would, I think, be difficult to justify to Parliament and public a more rigid attitude towards China, out of deference to India.' 59 Likewise, absent the United States' dyspeptic hostility to Chinese communism, which had grown out of the Truman administrations 'loss' of China in 1949 and been supercharged by the Korean War, Whitehall recoiled at the possibility

\footnotetext{
${ }_{55}^{55}$ Fry (Djakarta) to Warner (FO), 28 November 1962, FC1061/290, FO 371/164924, TNA.

${ }_{56}^{56}$ Moore minute, 21 February 1963, FC1061/36, FO 371/170670, TNA.

${ }^{57}$ Gore-Booth to CRO, 28 December 1962, FC 1061/20, FO 371/170669, TNA.

58 'UK Brief for NATO Far Eastern Experts Meeting', Paris, 14 March 1962, FO 371/164871, TNA. isep?

${ }^{59}$ Home to Sandys, 11 January 1963, DO 196/4, TNA. șẹp?
} 
of engaging hundreds of millions of Chinese in a wider war. Disturbed by the Kennedy government's pugnacity, British officials expressed unease that, 'the Americans ... view with much greater equanimity than we ... the prospect of a shooting war developing between the West and China. ${ }^{60}$

Impressed by the 'restraint' that he felt the Chinese had displayed in the face of Indian 'provocation,' John Addis, and his colleagues within the Foreign Office, nevertheless sought to frame his analysis of the border conflict in a manner that best advanced wider British political interests. This necessarily required that Addis strike a delicate balance between downplaying what the FO considered to be a large measure of Indian culpability for the war, while, at the same time, not unduly sacrificing the accuracy of his analysis. Addis assured the FO that in his final report he would, 'cut out much material that would on the one hand have put the behavior of the Chinese Government in a more favourable light and on the other hand would have shown up the weaknesses of the Indian Government's case...' Specifically, Addis confirmed that having consulted an array of documentary evidence, his analysis would omit:

...a number of passages which give a poor impression of the Indian Government's good sense and good manners. The final version [of the report] thus reflects even less accurately than the first draft the extent to which the Indian Government's presentation of their case to the Chinese Government has been arrogant and dogmatic, laying down the law and admitting to argument, magisterial and condescending, endlessly repetitive and never letting the overworked point go, quibbling and argumentative for the sake of arguing, and withal inconsistent and mendacious and applying different standards to the Chinese case and their own. ${ }^{, 61}$

In its final form, Addis' paper drew effusive praise from the Foreign Office. One FO analyst commented admiringly that as a background treatise on the border war, 'I doubt if Mr. Addis' work will be bettered for many years.' ${ }^{62}$ Sir Crawford MacLehose, head of the FO's Far Eastern department, wrote to Addis to congratulate him on the production of, 'a most admirable study, and just the sort of thing we have badly needed here for purposes of historical reference.' ${ }^{63}$ In general, Addis was deemed by his colleagues to have compiled, 'a much more satisfactory basic document than Mr. Lamb's rough and ready jottings.' Categorising the British diplomat's account of the border dispute as 'the answer to a maiden's prayer,' the FO was satisfied that it furnished, 'all the information we are ever likely to need on the history of the Sino-Indian border dispute. The paper... only rarely departs from strict objectivity...I think we could well make it our bible on the history of the dispute prior to last year's fighting.' Less strident than Lamb had been in support of the Chinese position, Addis nonetheless impressed senior FO staff by hinting at, "the absolute consistency with which the Chinese have presented their very presentable case, in contrast to the wavering and often self-contradictory line taken by the Indians.' 'It is hard to see where the Chinese have put a foot wrong,' another Foreign Office official surmised, 'laying aside the principle of resort to force: even on this, it may be noted that the Indians were the first to threaten war. ${ }^{, 64}$

\footnotetext{
60 'The Indian War Machine,' 29 March 1963, PREM 11/4301, TNA. iLEep'

${ }^{61}$ Addis to MacLehose, 23 May 1963, FC1061/83, FO 371/170671/,TNA.

${ }^{62}$ Buxton minute, 24 May 1963, FC1061/55, FO 371/170671, TNA.

${ }^{63}$ MacLehose to Addis, 30 April 1963, FC1061/55, FO 371/170671, TNA.

${ }^{64}$ Norton minute, 23 April 1963, FC1061/55, FO 371/170671, TNA.
} 
Once it had digested Addis' analysis, the Commonwealth Relations Office reacted to the report with undisguised horror. In a stinging memorandum fired off to the Foreign Office, Eleanor Emery, head of the CRO's South Asia department, excoriated Addis for 'accept[ing] unquestioningly the basic Chinese hypotheses,' and failing to approach the border issue with any reasonable sense of 'impartiality'. 'What worries us about Mr. Addis's paper,' the CRO fumed, '... is that it gives the appearance of being a factual and objective account of the dispute. But that is just what it is not...' Branding Addis' insistence that China had the stronger claim to the contested border areas as 'baffling', the CRO turned the diplomats own charge of sophistry on its head, suggesting that it was Addis, and not Indian officials, who had dissembled. 'Mr. Addis, while finding ways, some of them doubtful, of minimising the evidence of Chinese bad faith and casuistry,' the Foreign Office was enjoined, 'makes the most of any dubious element in the Indian presentation of the case. Even the weakest Chinese argument seems to remain arguable. ${ }^{65}$

The assault on Addis' integrity saw a bitter war of words break out between the FO and CRO. Amongst Addis' indignant colleagues, the CRO's protest was dismissed as unjustified and unbalanced, and received short shrift. 'The C.R.O.'s accusation of bias [against Addis],' one official postulated, 'stems from the fact that they are so imbued with the Delhi viewpoint (shades of Curzon hovering over Nehru's desk) that impartiality seems like bias to them.' Equally revealing of the regard in which Chinese culture and diplomacy were held within the ranks of its Far Eastern department, FO officials concluded that any bias on the part of Addis, if indeed it existed at all, undoubtedly stemmed from 'irritation at the devious and illogical way in which the Indians set to work. ${ }^{66}$ Significantly, such anti-Indian prejudice was not confined to the Foreign Office alone. Towards the end of 1962, no less a figure than Harold Macmillan had remarked, with evident distaste, that the Sino-Indian war had compelled his government to assist, 'people [Indians] who for 12 years or more have attacked us [Britain] ... like a camel looking down his nose at you. ${ }^{67}$ Indeed, the yawning political and cultural chasm separating attitudes to the border dispute within the different sections of the Whitehall bureaucracy appeared to be all but unbridgeable. 'I doubt,' one prominent FO official observed in May 1963, 'we can ever reconcile our views on this dispute with C.R.O.'s. ${ }^{, 68}$

Simmering tension between the Foreign Office and CRO over Addis' paper threatened to boil over in the spring, when the Indian government got wind of its contents. One condition of Addis' tenure at Harvard's Centre for International Affairs stipulated that the research findings of Fellows must be presented at a seminar open to the University's academic community. Addis delivered his paper at Harvard on 13 March. Immediately prior to his address, Addis informed Ted Peck that he proposed:

... to say that the facts seem to me to show that for the Chinese this quarrel with India has been essentially a border dispute not of their choosing; and that I therefore rather discount the suggestions that the border dispute with India has been sought by the Chinese as preparation for the annexation of India, or as a means of eliminating competition from India for the Leadership of Asia by crippling her economy and damaging her prestige, or as a factor in the dispute with the Soviet Union. ${ }^{69}$

\footnotetext{
${ }^{65}$ Emery to Flack, 12 December 1963, FC 1061/141, FO 371/170675, TNA.

${ }^{66}$ Buxton minute, 15 January 1964, FC 1061/141, FO 371/170675, TNA.

${ }^{67}$ Kennedy/Macmillan talks, Nassau, 20 December 1962, FRUS, 1961-63, Vol. XIX, 451.

${ }^{68}$ Norton minute, 27 May 1963, FC1061/55, FO 371/170671, TNA.

${ }^{69}$ Addis to Peck, 5 March 1963, FC1061/55, FO 371/170671, TNA.
} 
Addis was not alone in contending that China had no ideological axe to grind with India, and that Beijing had good reason for wanting to avoid a major military confrontation with its southern neighbour. Back in December 1962, having met with Chou En-lai in Beijing, Malcolm MacDonald impressed upon Macmillan's government his belief that China's ambitions with respect to India were strictly limited. 'The Chinese would be very reluctant to get involved [with India] more than they were already: they needed peace because they knew it would take a long time to build up their economy,' MacDonald reported. 'They [China] did not wish to go further because they knew that if they did the Americans would become involved...the Chinese feared war with the United States. ${ }^{, 70}$

For British diplomats to privately challenge the official government line that India was an innocent victim of Chinese aggression was one thing. To air such thoughts in public, was quite another. At the beginning of May, British officials in New Delhi were aghast to discover that members of India's delegation to the United Nations in New York had reported Addis as publicly declaring the, 'Indian case over the SinoIndian boundary dispute is historically unsound.' The British high commission in India's capital despatched an urgent cable back to the CRO asking for clarification. The delegation's source, it transpired, had been an Indian diplomat based at Harvard, who had attended Addis' seminar back in March. ${ }^{71}$ Having hurriedly consulted the Foreign Office, the CRO began to dissemble. The high commission in New Delhi was instructed to inform Indian colleagues that Addis' paper was, 'a purely personal and academic production, based on public sources, and does not purport to (and in the circumstances could not) represent the views of Her Majesty's Government, which was not consulted in any way. It therefore has no official status whatsoever.' Further discussion with Indian officials on the subject was to be avoided. The furore that was likely to result were a copy of Addis's paper leaked to the Indian press would, the CRO underlined, complicate on-going efforts by the United Kingdom to furnish India with moral and practical support in the wake of the border war, "which none of us would want. ${ }^{72}$ Unsurprisingly, the Foreign Office took an altogether more sanguine view of Addis' indiscretion. 'I am afraid, Crawford MacLehose noted laconically, 'that Mr. Addis has aired his views too noticeably.' 73 'I wonder if,' another senior Whitehall mandarin observed wistfully, 'it is wise to give F.O. officials a year to think at Harvard!?74

The diplomatic flap triggered by Addis' Harvard paper witnessed the Foreign Office move to distance itself from its diplomat's research project. Privately, some FO officials began to wonder if, on reflection, Addis hadn't been too severe in condemning Nehru's government. Pointing to Britain's own unhappy experience of confronting European fascism in the 1930s, W.J. E. Norton, noted that, 'If the Indians vacillated between appeasement and retaliation in the face of an authoritarian neighbour bent on expansion, they were not the only democracy to have found itself in this dilemma in the last 30 years, nor the only one to have been caught militarily unprepared when the time came. ${ }^{75}$ Nonetheless, a majority of senior FO officials continued to heap praise on Addis' interpretation of the border dispute. 'Although we

\footnotetext{
${ }^{70}$ Conversation between Macdonald and Peck, 20 December 1962, FC 1061/8, FO 371/170669, TNA.

${ }^{71}$ Delhi to CRO, No. 1245, 1 May 1963, FC1061/55, FO 371/170671, TNA.

${ }^{72}$ CRO to Delhi, No. 1548, 4 May 1963, FC1061/55, FO 371/170671, TNA.

${ }^{73}$ MacLehose minute, 6 April 1963, FC1061/55, FO 371/170671, TNA.

${ }^{74}$ McKenzie-Johnson minute, 30 May 1963, FC 1061/83, FO 371/170673, TNA.

${ }^{75}$ Norton minute, 30 May 1963, FC 1061/83, FO 371/170673, TNA.
} 
have recently had to dissociate ourselves officially from its [Addis'] argument,' one FO official recorded on 29 May, 'the fact remains that the paper is about as good a basic documents of history of the dispute as we are likely to get for a long time... the overall impression is of a balanced and factual study.' More practically, the Foreign Office reasoned that, while, 'with luck', it might never need to 'declare our views on the rights and wrongs of this dispute,' looking forward, Ministers might well demand a reasoned assessment of the border issue. In which case, Addis' work was held up as offering the best template. ${ }^{76}$

No sooner had the British weathered the turbulent political waters occasioned by Addis' intervention in the border dispute, than the figure of Alistair Lamb re-entered the Sino-Indian drama. Lamb had decided to publish a 'little book on the Sino-Indian boundary question.' Confessing that his manuscript was unlikely to 'win many friends in New Delhi as it does not come out $100 \%$ in support of Indian arguments,' Lamb nevertheless professed that he had, 'leaned over backwards not to appear pro-Chinese, which I certainly am not.' Whatever Lamb's views on China, his scholarship evidenced little empathy for Indian officials who, at one point, he characterised as, 'devious Hindus, who are not always obsessed with the letter [of legal documents] when they can argue about the spirit. ${ }^{77}$ The Indian government certainly considered Lamb to be anything but impartial in his approach to the border dispute. At the beginning of January 1964, Kewal Singh, India's deputy high commissioner in London, requested an urgent meeting with Sir Saville Garner, permanent undersecretary for Commonwealth Relations. Dispensing with the usual formalities, an exercised Singh informed Garner that he had learned 'with great concern' of Lamb's plan to publish an historical analysis of the border dispute. Lamb's book, Singh asserted presented, 'a monstrously partial account of the [border] matter... supported the Chinese case up to the hilt and was grossly unfair to the Indian side.' To make matters worse, Lamb's text was due to appear under the imprint of the Royal Institute of International Affairs, or Chatham House, the London-based policy institute with strong links to Whitehall. Noting that Chatham House was widely regarded as a semiofficial British organisation, Singh stated that by publishing Lamb's book the institute would legitimise its arguments, 'handing a considerable [public relations] advantage to the Chinese. ${ }^{78}$ Having been thrown on to the defensive by the force of Indian ire directed at Lamb's book, Garner repeated the misjudgement that Home had made in his earlier dealings with the Times, and agreed to intercede with Chatham House to see if anything could be done to assuage New Delhi's anxieties.

Before meeting with Garner, Singh paid two visits to Kenneth Younger, director of Chatham House, and a former British deputy foreign secretary. Anticipating that Lamb's book would cause a stir in New Delhi, Younger had taken the precaution of sending the Indian government a draft copy. In mid-December 1963, Singh made his first approach to Younger, who dismissed the Indian officials objections that the 'general tenor' of Lamb's work was anti-Indian. In early January, Singh returned to Chatham House, on this occasion accompanied by Sarvepalli Gopal. Having poured over Lamb's manuscript, Gopal came armed with a long list of objections to specific passages in the text, alongside a more general complaint surrounding the purportedly pro-Chinese agenda that it promoted. Younger remained unmoved. To the Indians consternation, the director of Chatham House rejected all the lengthy legal and technical objections tabled by Gopal, and instead insisted that Lamb's book would be

\footnotetext{
${ }^{76}$ McKennzie Johnston to CRO, 29 May 1963, FC1061/55, FO 371/170671, TNA.

${ }^{77}$ Lamb to Stevens, 15 May 1963, FC 1061/95, FO 371/170673, TNA.

${ }^{78}$ Saville Garner to Emery, 6 January 1964, FC 1061/2, FO 371/175929, TNA.
} 
published unchanged. Any grievance directed at the book by the Indian government, Younger stated baldly, would be "dealt with in the normal course of controversy afterwards. ${ }^{79}$

At the same time, in New Delhi, officials from India's Ministry of External Affairs brought identical complaints over Lamb's work to the door of the British high commission. Charging that the publication of Lamb's book would 'gratuitously provide ammunition to Chinese Government', the Indians warned their British colleagues that:

...public opinion here will react strongly if Chatham House seems to support the Chinese thesis about the boundary dispute, and much of the odium will fall on the British Government. It would probably be argued that H.M.G. were allowing a damaging attack on the basis of position India inherited from British India which they would not have allowed without protest where a British interest involved.

It was suggested to British officials that the CRO might 'discretely' approach Chatham House, and arrange for a prominent disclaimer to be included at the beginning of Lamb's book that made it abundantly clear that the opinions expressed within were in no way representative of the Royal Institute of International Affairs. In reporting the MEA approach to Whitehall, the high commission cautioned that were Lamb's book to be published, 'we shall have to consider urgently what line we are going to take in public, both in London and in Delhi.' One option put forward, was a reaffirmation, 'in general terms... of full British support for the validity of India's frontiers as inherited in 1947.' The potential public relations bonanza Lamb's book offered the Chinese deeply worried the British. 'I am bound to stress that this could be a serious matter [for Indo-British relations],' an official from the high commission forewarned the CRO. '...Mr. Lamb's book will make... really admirable material for communist propaganda to make a "trap for fools" at the expense of India and ourselves. $^{80}$

Characteristically, the Foreign Office took a dim view of any move to publicly reaffirm British support for the frontiers that India inherited in 1947. The Lamb affair, in the view of Crawford MacLehose, was strictly a matter for Chatham House and the less the British government had to do with it the better. It would be 'a great mistake', MacLehose contended, for Whitehall to let itself become too directly involved in what was an essentially Sino-Indian matter. 'It is an open question whether, if we had been in control of India between 1955 and 1962 we, like the Indians, would have refused to negotiate a settlement with the Chinese,' MacLehose argued. 'After all, what is involved is negligible in comparison to what we have accepted without a major international row, in China since 1947. ${ }^{81}$

On 15 January, pressure from the Indian government induced a deeply reluctant Garner to enter into a long discussion with Younger on the subject of Lamb's book. Garner found Younger in typically combative mood. Defending Chatham House's conduct, Younger emphasised that the Institute had been at pains to explain to the Indian government its plans to bring Lamb's work to press. Discounting Indian claims that the book was pro-Chinese, Younger assured Garner that, 'he was satisfied that Mr. Lamb was completely impartial and in fact his own view was that he had given India at least 85 per cent of her case.' Moreover, experts such as Hugh Richardson

\footnotetext{
79 Younger to Lamb, 13 January 1964, FC 1061/2, FO 371/175929, TNA.

${ }^{80}$ Delhi to CRO, No, 64, 8 January 1964, FC 1061/6, FO 371/175929, TNA.

${ }^{81}$ MacLehose minute, 10 January 1964, FC 1061/6, FO 371/175929, TNA.
} 
and Hugh Tinker, the eminent historian of South Asia, had read the manuscript and 'judged that Mr. Lamb had done a serious and responsible job.' Attempts by Gopal to cajole Chatham House into amending its standard publication disclaimer to suggest that Lamb's book was neither scholarly nor disinterested had, Garner was informed, been very badly received. Veiled threats issued by Gopal that Nehru might have to resign from his position as vice-president of Chatham House where Younger's position to remain unchanged, had met with a frosty riposte. 'If the Indian's really took this step,' a defiant Younger fumed, 'it would show them up in a very poor light. ${ }^{82}$

The CRO's failure to mollify Indian anger over the latest in a series of what New Delhi interpreted as distinctly unhelpful British interventions in the border dispute, perturbed Whitehall. British officials were disconcerted when Gopal tartly accused the CRO of reneging on an earlier commitment 'to stall off researches by Chinese or Communists' on the border question within the archives of the India Office Library. Though the Indian government had not 'suggested that Mr. Lamb is a communist,' a despairing Eleanor Emery reflected, the impression given by New Delhi was that Britain had let India down by allowing a hostile body, in the person of Alistair Lamb, access to official records on the border question. To Emery's intense irritation, the American Embassy in New Delhi reported that Indian Foreign Service Officers had been grumbling, 'with some bitterness that Alistair Lamb was the C.R.O.'s "adviser" on the Sino-Indian Frontier.' 83

In fact, as Gopal confided to Peter Petrie, first secretary at the British high commission the Lamb episode proved instrumental in hardening an already, 'strong belief in the Ministry [MEA] that the British government wanted India to settle immediately with China by surrendering 7,000 square miles of Indian-claimed territory in Ladakh.' Petrie learned to his vexation that an anti-British attitude had hardened inside Indian government circles due, in part, to the misperception that a book hostile to Nehru's government had been authored by, 'Mr Lamb... the official adviser of the C.R.O. on the Sino-Indian frontier...' Furthermore, resentment directed at London had been cemented in India, Gopal revealed, by, 'the similar views advanced by other "fringes of the [British] Establishment" such as Chatham House and The Times...' More broadly, a growing sense in India that Lamb's viewpoint was indeed pro-Chinese, and that it reflected British government policy, threatened to have wider and far more serious consequences for New Delhi's management of the Sino-Indian dispute. Specifically, Gopal confided to Petrie that two schools of thought on the border question had developed in the Indian government. One, held by 'hawks', including himself and M. J. Desai, secretary-general in the MEA, maintained that the Chinese held fundamentally aggressive intentions towards India, and would attack across the border again, most probably in 1966. The other perspective, held by 'Doves', including India's ambassadors in Karachi and Cairo, and the charge d'affairs in Beijing, maintained that Sino-Indian differences were superficial and that a negotiated territorial remained possible. Gopal and his fellow 'Hawks', the British were informed, 'were concerned that... the Lamb school of thought would encourage the "doves" in India who wanted to appease China in order to have their hands free to deal with Pakistan. ${ }^{84}$ Whitehall was not the only bureaucracy, it seemed, that had been polarized by the Sino-Indian war.

\footnotetext{
${ }^{82}$ Saville Garner to Emery, 16 January 1964, FC 1061/2, FO 371/175929, TNA.

${ }^{83}$ Emery to O'Brien (Delhi), 6 March 1964, FC 1061/2, FO 371/175929, TNA.

${ }^{84}$ Petrie Minute, 4 April 1964, F1051/4, FO 371/175897, TNA.
} 
Back in Whitehall, by the spring of 1964, unease had mounted that the divergent viewpoints held by the CRO and the Foreign Office in respect of the border dispute risked undercutting Britain's regional policy in Asia, and provoking a schism with the UK's American partner. In particular, the Information Research Department (IRD) complained that infighting between government departments in London was making its work in Asia doubly difficult. A shadowy organisation operating within the FO, and with close links to the British Secret Intelligence Service, or MI6, the IRD had been established by the Attlee administration back in 1948 to counter the spread of communist propaganda at home and abroad. In April 1964, one IRD official observed that Britain and the United States had 'already publicly ranged ourselves on the Indian side by our immediate offer of military assistance in [the] face of Chinese aggression. We must obviously follow this up in all ways we can, including our propaganda. ${ }^{, 85}$ The problem, as IRD saw it, was that incessant squabbling between the CRO and FO over the Lamb and Addis papers, made the maintenance of a consistent and effective British line on the Sino-Indian dispute all but impossible. It was only practicable to 'support the Indians in condemning Chinese aggressiveness... intransigence and brutality', Britain's propagandists underscored, if the Whitehall spoke with one voice on border conflict. ${ }^{86}$

Notably, to the consternation of IRD staff, the Foreign Office's Research Department (FORD) had taken exception to what it decried as 'misleading' articles circulated by the IRD that appeared motivated by 'the need not to offend India.' The 'manifestly different' stances adopted by the FO and CRO on the border question exasperated the IRD, which asked pointedly how it was expected to address the conundrum of "balancing "a need not to offend India" against "a need not to offend China" - if that is indeed what we must do. ${ }^{87}$ Resolving this paradox, IRD officials noted, was particularly urgent given that the Addis and Lamb papers continued to be held up as evidence by elements within the Indian government that, "Britain is basically anti-Indian in the Sino-Indian dispute" and that the Foreign Office are giving "pro-Chinese briefings" to people visiting India.' Not unreasonably, the IRD rationalised that, 'It is for the Far Eastern Department [of the Foreign Office] and the C.R.O. to sort out the policy issue. ${ }^{88}$ To the chagrin of the IRD, arguments between the Foreign Office and CRO over the Sino-Indian border conflict would remain unresolved, and rumble on well into the 1960s.

Britain's attempts to understand why the long simmering Sino-Indian border dispute escalated suddenly and unexpectedly into hostilities between India and China in October 1962, uncovered a deep schism at the heart of the Whitehall over the direction of the United Kingdom's foreign policy in South Asia. In the aftermath of the Sino-Indian border war, the Foreign Office became convinced that New Delhi's territorial claims in relation to China rested on an erroneous, if not spurious, interpretation of documentary evidence. Moreover, as one FO official noted, 'The fact that the British and United States Governments declared that the Chinese committed naked aggression [against India] is evidence of the political attitudes of the British and American Governments, but does not help one to understand the Sino-Indian situation. ${ }^{89}$

\footnotetext{
${ }^{85}$ Merrells (IRD) minute, 24 April 1964, FC 1061/141, FO 371/170675, TNA.

${ }^{86}$ Dalton minute, 29 April 1964, FC 1061/141, FO 371/170675, TNA.

${ }^{87}$ Francis (IRD) minute, 3 April 1964, FC 1061/141, FO 371/170675, TNA.

${ }^{88}$ Dalton minute, 29 April 1964, FC 1061/141, FO 371/170675, TNA.

${ }^{89}$ Buxton minute, 15 January 1964, FC 1061/141, FO 371/170675, TNA.
} 
As Chinese troops poured across India's borders, the British government prevaricated over how to respond to the crisis unfolding in the Indian subcontinent. The Macmillan administration's initial reaction to the plight of a fellow commonwealth country was ponderous and equivocal. A degree of schadenfreude in respect of India's misfortune permeated the thoughts and deeds of senior members of the British establishment, Macmillan included. In the aftermath of the Sino-Indian border war, cultural prejudice coalesced with strategic considerations inside the Foreign Office, where officials began to question whether Britain's long-term interests were best served by continuing to offer India unconditional backing in its conflict with China. Rather than persist with what it categorised as a Western tendency to vilify the PRC and 'often distort the historical record in order to attack China,' elements within the FO suggested that the border war had underscored the need for London to adopt less doctrinaire approach to Sino-Indian relations. ${ }^{90}$ The British government, in other words, would 'support Indian better if our [UK] eyes are open both to what the Indians were doing and to the probable motives of the Chinese.' 91 Although willing to 'gloss over' purported Indian culpability for the border conflict in order to forestall a fracture in relations with New Delhi, and to appease to London's American partners, the FO continued to lobby for a more qualified and less partisan British approach to South Asia's cartographic conflict. ${ }^{92}$

The Commonwealth Relations Office saw things very differently. From the CRO's vantage point, colleagues in the FO appeared biased towards China, dismissive of Nehru's government, and determined to promote a policy that would 'destroy the basis of United Kingdom support for India.' ${ }^{93}$ Still, once the border conflict had abated, and it became clear that a truce between India and China would hold, senior figures with the CRO gradually came to the conclusion that Britain might well need to modify its approach to South Asian affairs. The propensity that had existed within the CRO to interpret relations with India, China, and their South Asian neighbours, through an outmoded colonial prism, was replaced by a more detached and utilitarian approach to the subcontinent. In 1965, it would be Britain's unhappy involvement in a separate territorial conflict in South Asia, encompassing another malignant cartographic legacy of empire, that between India and Pakistan over Kashmir, which would see the CRO embrace a regional policy of 'obtrusive disengagement', akin to that promoted by the Foreign Office. ${ }^{94}$ The genesis of British retrenchment from South Asia that occurred in the latter half of the 1960s, however, can to be found, in large part, in the policy debates that occurred within Whitehall between the CRO and FO at the pinnacle of the United Kingdom's intervention in post-independent India, in the immediate aftermath of the Sino-Indian border war of 1962.

\footnotetext{
${ }^{90}$ Buxton minute, 15 January 1964, FC 1061/141, FO 371/170675, TNA.

${ }^{91}$ Buxton minute, 12 February 1964, FC1061/33, FO 371/175929, TNA.

${ }^{92}$ Flack to Emery, 22 June 1964, FC 1061/33, FO 371/175929, TNA.

${ }^{93}$ Buxton minute, 12 February 1964, FC1061/33, FO 371/175929, TNA.

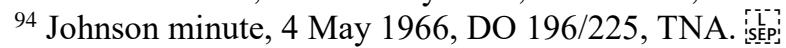

